\title{
Urgences
}

\section{Un brigadier...}

Brigitte Leblanc

Numéro 13, mars 1986

\section{Éclats d'atelier}

URI : https://id.erudit.org/iderudit/025206ar

DOI : https://doi.org/10.7202/025206ar

Aller au sommaire du numéro

\section{Éditeur(s)}

Urgences

\section{ISSN}

0226-9554 (imprimé)

1927-3924 (numérique)

Découvrir la revue

\section{Citer ce document}

Leblanc, B. (1986). Un brigadier... Urgences, (13), 25-25.

https://doi.org/10.7202/025206ar d'utilisation que vous pouvez consulter en ligne.

https://apropos.erudit.org/fr/usagers/politique-dutilisation/ 


\section{Brigitte Leblanc}

Un brigadier se tenait debout devant un immense monument garni de taches noires, où on pouvait distinguer une figure déchirante qui se hissait. On fit monter sur une grande toile blanche, qui lui servirait sûrement d'abri, un gîte décoré de milliers de lumières. Plusieurs curieux se propageaient dans les rues pour assister à cette grande découverte faite par des géologues fort savants. On dut enlever avec patience et diplomatie les débris qui s'agitaient depuis de longues années, parmi les parcelles de poussière blanche. Quelques minutes encore et ce fut le moment crucial, le moment tant attendu de tous. Chacun, le souffle retenu, regardait avec étonnement le blanc regard aux yeux bridés du gitan.

On déroula les plus beaux tapis, pour permettre aux grands maîtres le droit de s'approcher et d'analyser de plus près ce curieux personnage venu en apportant avec lui des décombres. Les maîtres remontèrent leur vison, comme si le vent s'était levé et avait donné des yeux vivants à ce monument. Une atmosphère pesante régnait quand, du bout des doigts, un des géologues frôla avec hésitation le front bombé de ce gitan, et que la pierre se fendit pour faire place à des grains de poussière. Cette nuit-là, la ville ne dormit pas. Car ces petites parcelles de poussière blanche avaient malgré elles apporté la vie au blanc regard aux yeux bridés du gitan. 